\title{
Nephric lineage specification by Pax2 and Pax8
}

\author{
Maxime Bouchard, Abdallah Souabni, Markus Mandler, Annette Neubüser, and Meinrad \\ Busslinger ${ }^{1}$ \\ Research Institute of Molecular Pathology, Vienna Biocenter, A-1030 Vienna, Austria
}

The mammalian kidney develops in three successive steps from the initial pronephros via the mesonephros to the adult metanephros. Although the nephric lineage is specified during pronephros induction, no single regulator, including the transcription factor Pax2 or Pax8, has yet been identified to control this initial phase of kidney development. In this paper, we demonstrate that mouse embryos lacking both Pax2 and Pax8 are unable to form the pronephros or any later nephric structures. In these double-mutant embryos, the intermediate mesoderm does not undergo the mesenchymal-epithelial transitions required for nephric duct formation, fails to initiate the kidney-specific expression of Lim1 and c-Ret, and is lost by apoptosis $1 \mathrm{~d}$ after failed pronephric induction. Conversely, retroviral misexpression of Pax2 was sufficient to induce ectopic nephric structures in the intermediate mesoderm and genital ridge of chick embryos. Together, these data identify Pax2 and Pax8 as critical regulators that specify the nephric lineage.

[Keywords: Pax2; Pax8; genetic redundancy; kidney development; mesenchymal-epithelial transition; lineage specification]

Received June 28, 2002; revised version accepted September 20, 2002.

Kidney development in mammals and birds proceeds in three successive steps that are all characterized by the mesenchymal-to-epithelial transformation of intermediate mesoderm cells. The development of the first kidney, the transient pronephros, is initiated by signals from the somite and surface ectoderm that induce cells in the intermediate mesoderm to undergo the transition to epithelial cells forming the nephric duct (Obara-Ishihara et al. 1999; Mauch et al. 2000). The caudal migration of the nephric duct subsequently induces the adjacent nephrogenic mesoderm to aggregate and form the tubules of the mesonephros, the second embryonic kidney. On further extension, the nephric duct reaches the metanephrogenic mesenchyme at the level of the developing hindlimb, where the ureteric bud evaginates from the nephric duct and invades the surrounding mesenchyme. Both the ureter and mesenchyme subsequently undergo reciprocal inductive interactions to form the nephrons and collecting ducts of the metanephros, the third and adult kidney. Ultimately, the development of the metanephros therefore depends on the proper formation of the nephric duct during pronephros induction (for review, see Saxén 1987; Vainio and Müller 1997).

Targeted mutagenesis in the mouse has identified a multitude of genes that are important for normal kidney

\footnotetext{
${ }^{1}$ Corresponding author.

E-MAIL busslinger@nt.imp.univie.ac.at; FAX 43-1-798-9370.

Article and publication are at http://www.genesdev.org/cgi/doi/10.1101/ $\operatorname{gad} .240102$.
}

development (for review, see Kuure et al. 2000; Davies and Brändli 2002). The majority of these genes are essential for proper morphogenesis of the metanephros with the most severe phenotypes being caused by the inactivation of the transcription factor genes Lim1 (Shawlot and Behringer 1995), WT1 (Kreidberg et al. 1993), and Pax2 (Torres et al. 1995; Favor et al. 1996). Lim1 mutant embryos fail to develop a metanephros and gonads (Shawlot and Behringer 1995), although a nephric duct is initially formed, but then degenerates in the posterior part of the mesonephros (Tsang et al. 2000). The Wilms' tumor suppressor gene WT1 is also necessary for metanephros and gonad development, as the metanephric mesenchyme is unresponsive to inductive signals and undergoes apoptosis in the absence of WT1 function (Kreidberg et al. 1993). The mesonephros, however, still develops in WT1-deficient embryos, although its most caudal tubules fail to form (Sainio et al. 1997). Interestingly, the Pax2 gene is still expressed in the mesonephros of both Lim1 and WT1 mutant embryos (Donovan et al. 1999; Tsang et al. 2000), suggesting that Pax2 acts upstream of these two transcription factors in kidney development. Pax2 is the first known kidney-specific gene to be expressed in the pronephros of the mouse embryo (Bouchard et al. 2000). Despite this early expression, the mesonephric duct is still formed in Pax2-deficient embryos, but then fails to extend to the metanephrogenic mesenchyme because of its rapid degeneration (Torres et al. 1995). As a consequence, the metanephros and genital tracts never develop in Pax2 mutant mice 
(Torres et al. 1995; Favor et al. 1996). Importantly, however, none of the known gene mutations-including Pax2-interferes with the earliest phase of kidney development, that is, the initial formation of the pro- and mesonephros.

Pax8, another member of the Pax2/5/8 family, is also expressed during pro-, meso-, and metanephros development (Plachov et al. 1990; Pfeffer et al. 1998). Surprisingly, kidney organogenesis is normal in Pax8 mutant mice that die postnatally of a defect in thyroid gland development (Mansouri et al. 1998). By gene replacement in the mouse, we have shown recently that the proteins of the Pax2/5/8 family can substitute for each other in development because of their equivalent biochemical function (Bouchard et al. 2000). By analyzing Pax2,Pax8 double-mutant embryos, we now demonstrate that these two transcription factors have redundant functions in kidney development. Pax2 and $\operatorname{Pax} 8$ together are required for the formation of the proand mesonephros, as the intermediate mesoderm of Pax $2^{-/-} \mathrm{Pax} 8^{-/-}$embryos was unable to undergo the initial mesenchymal-epithelial transitions and to express the early kidney-specific genes c-ret and Lim1. In complementary experiments, the retroviral misexpression of Pax2 was sufficient to induce ectopic nephric structures in the intermediate mesoderm and genital ridge of chick embryos. Together, these data demonstrate that Pax 2 and Pax 8 are both necessary and sufficient for specifying the nephric lineage.

\section{Results}

Inactivation of the Pax8 gene

Exon 3 of the Pax 8 gene codes for the $\mathrm{N}$-terminal part of the paired domain that is indispensable for DNA binding of the Pax2/5/8 transcription factors (Czerny et al. 1993). Using homologous recombination in embryonic stem (ES) cells, we therefore inactivated the $\operatorname{Pax} 8$ gene by replacing exon 3 with an in-frame insertion of a cre recombinase gene together with a neomycin (neo) resistance gene (Fig. 1A). Heterozygous $\mathrm{Pax} 8^{\text {neo/+ }}$ mice were obtained by blastocyst injection of targeted ES cells and were shown to express Cre activity in all Pax8 expression domains (Plachov et al. 1990), including the developing kidney, ear, thyroid gland and midbrain-hindbrain boundary region (data not shown). Homozygous $\mathrm{Pax} 8^{\text {neo/neo }}$ mice were born at a Mendelian frequency, then became severely growth-retarded and died at weaning age of agenesis of the thyroid gland (data not shown). As the same phenotype was described previously for another Pax8 null mutation (Mansouri et al. 1998), we refer to the $P a x 8^{\text {neo }}$ gene in all subsequent experiments as Pax $8^{-}$allele.

\section{Cooperation of Pax2 and Pax8 in the development of the urogenital system}

The Pax 8 gene is known to be expressed together with Pax2 during mouse kidney development (Plachov et al. 1990; Dressler et al. 1990). Nevertheless, Pax8 mutant embryos develop a normal urogenital system (Fig. 2B) (Mansouri et al. 1998), whereas Pax2 mutant embryos fail to form a metanephros and genital tracts because of a defect in caudal elongation of the nephric duct (Torres et al. 1995; Favor et al. 1996; Bouchard et al. 2000). Therefore, it is conceivable that Pax2 may compensate for the loss of Pax8 in kidney development of $\mathrm{Pax}^{-/-}$embryos. To test this hypothesis, we crossed $\mathrm{Pax}^{+/-}$mice with $\mathrm{Pax}^{+/-}$mice (Bouchard et al. 2000) to generate an allelic series of $\operatorname{Pax} 2, \operatorname{Pax} 8$ doublemutant embryos. Analysis of the urogenital system of
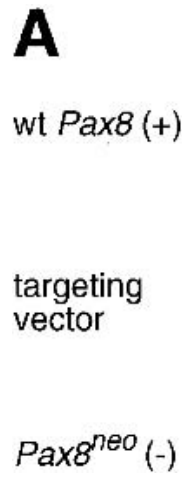
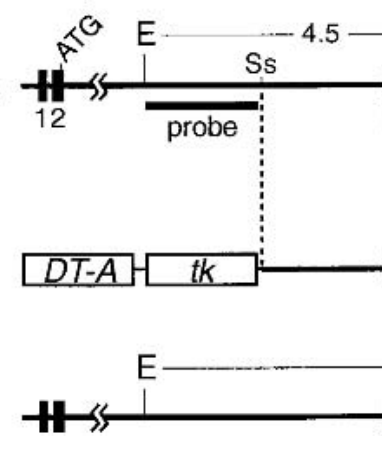

Figure 1. Inactivation of the Pax8 locus by insertion of a cre gene. (A) Structure of the wild-type and targeted Pax 8 loci. The cre gene was fused in frame to Pax8 exon 3 followed by a neomycin (neo) resistance gene and an SV40 polyadenylation site (pA). The herpes simplex virus thymidine kinase $(t k)$ and diphteria toxin A $(D T-A)$ genes were used for counterselection against random integration in ES cells. The neo expression cassette was flanked by frt sites (red arrowheads) that mediate deletion by the FLP recombinase. Correct targeting was verified by Southern blot analysis of EcoRI-digested DNA with the indicated probe. The lengths of DNA fragments are indicated in kilobases. The Pax8 exons are numbered according to Okladnova et al. (1997) with exon 3 coding for the N-terminal part of the paired domain. The $P a x 8^{\text {neo }}$ allele codes for a fusion protein consisting of the first 12 amino acids of Pax 8 (underlined) linked to the SV40 nuclear localization signal and the N-terminal Cre protein sequences (boldface type): MPHNSIRSGHGGPKKKRKVSNLL. E, EcoRI; N, NcoI; Sa, SacI; Ss, SspI. (B) Southern blot analysis of EcoRI-digested tail DNA from wild-type (+/+) and heterozygous (+/-) Pax8 mutant mice. 
Bouchard et al.

Figure 2. Development of the urogenital system in Pax2, Pax8 mutant embryos. (A$D)$ The urogenital system of male E18.5 embryos of the indicated genotypes was dissected and photographed. The hypoplastic kidneys of $\mathrm{Pax}^{+/-} \mathrm{Pax} 8^{+/-}$embryos $(C)$ were approximately fourfold smaller than control kidneys $(A, B)$. $\mathrm{Pax}^{+/-} \mathrm{Pax} 8^{-/-}$ embryos $(D)$ failed to develop a kidney, ureter, and genital tract (vas deferens), whereas the adrenal gland, testis, and bladder formed normally. $(E, F)$ Kidney sections stained with hematoxylin and eosin. The nephric tubules and glomeruli were reduced in number and the stromal component was increased in the hypoplastic Pax2 $2^{+/-} \mathrm{Pax}^{+/-}$kidney $(F)$ compared with the control embryo $(E)$ at E18.5. a, adrenal gland; b, bladder; g, glomerulus; k, kidney; $\mathrm{s}$, S-shaped body; st, stroma; t, testis; tu, tubule; $\mathrm{u}$, ureter; ut, ureteric tip; $\mathrm{v}$, vas deferens.
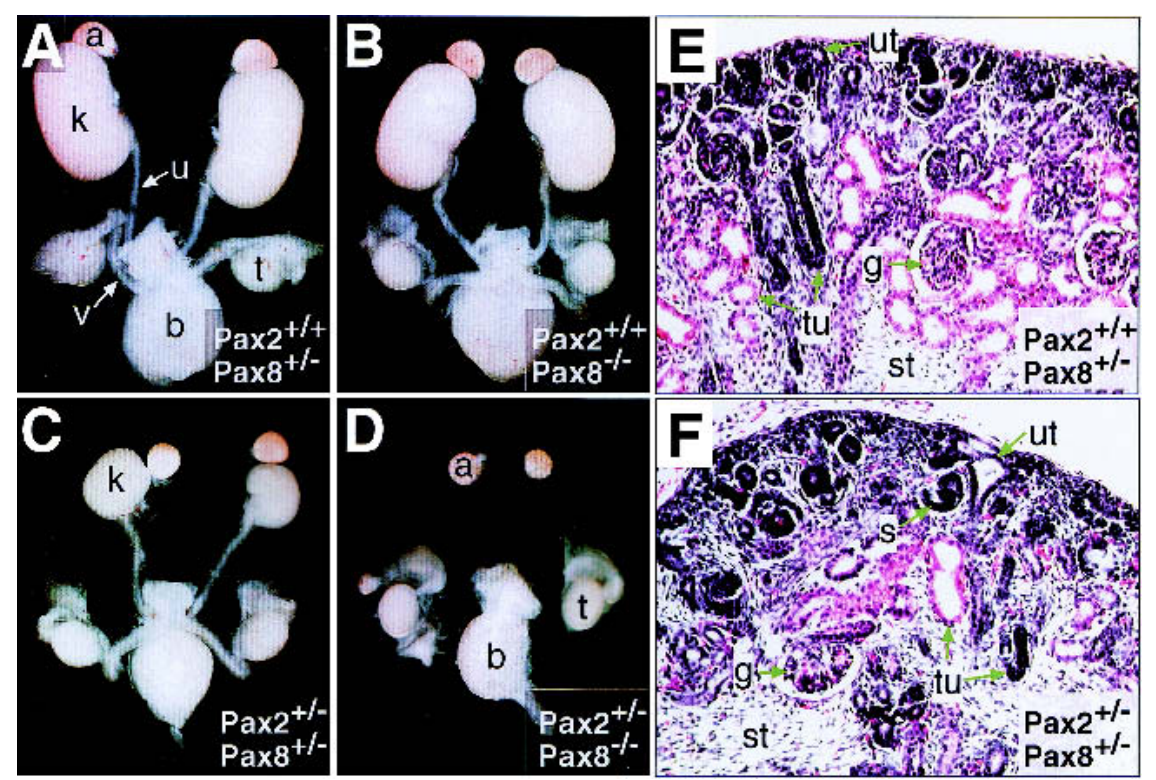

18.5-d embryos demonstrated that the metanephros of $\mathrm{Pax}^{+/-} \mathrm{Pax} 8^{+/-}$embryos was bilaterally reduced to only $\sim 25 \%$ of the size of control littermates (Fig. 2A,C). This reduction is more severe than in $\mathrm{Pax}_{2}{ }^{+/-}$embryos, which develop kidneys at $\sim 60 \%$ of the normal size (Porteous et al. 2000; data not shown). Apart from the hypoplastic kidney, all other components of the urogenital system developed normally in compound heterozygous embryos (Fig. 2C). Histological examination of $\mathrm{Pax}^{+/-} \mathrm{Pax}^{+/-}$ kidneys revealed a perturbed architecture characterized by a reduced number and irregular arrangement of nephric tubules and glomeruli (Fig. 2E,F). The uninduced mesenchyme at the cortex and the mesenchymal stroma throughout the kidney were increased compared with control embryos, therefore demonstrating inefficient induction of tubules in compound heterozygous embryos. The remaining nephrons of $\mathrm{Pax}^{+/-} \mathrm{Pax}^{+/-}$kidneys were, however, functional as double-heterozygous animals survived for more than 18 mo.

A recurrent phenotype of $\mathrm{Pax}^{+/-} \mathrm{Pax}^{+/-}$females was vaginal atresia, which is characterized by the presence of a blind-ending vagina. The penetrance of this phenotype was $100 \%$ on a mixed C57BL/6x129/Sv genetic background, whereas it was $43 \%$ in $\mathrm{C} 3 \mathrm{H} / \mathrm{He}$ females (data not shown). Minor malformations of the open vagina were, however, still observed in compound heterozygous $\mathrm{C} 3 \mathrm{H} / \mathrm{He}$ females. A significant proportion of the Pax $2^{+/-} \mathrm{Pax}^{+/-}$males also failed to give rise to any progeny. Ductal obstruction of the genital tracts rather than a defect in sperm formation is the likely cause of this phenotype, as $\mathrm{Pax}^{+/-} \mathrm{Pax}^{+/-}$sperm could be used for in vitro fertilization of $\mathrm{Pax}^{+/-} \mathrm{Pax}^{+/-}$oocytes to generate viable off-spring after transplantation into foster mothers (data not shown). As a consequence of these genital phenotypes, Pax2,Pax8 double-mutant embryos could be generated only by crossing compound heterozygous $\mathrm{C} 3 \mathrm{H} / \mathrm{He}$ mice.

$\mathrm{Pax} 2^{+/-} \mathrm{Pax}^{-/-}$embryos entirely failed to form a meta- nephros, ureter, and genital tracts, indicating that a single wild-type Pax2 allele in a Pax8 mutant background is not sufficient to support the development of an adult kidney (Fig. 2D). This phenotype is similar to that of Pax2 mutant embryos (Torres et al. 1995; Bouchard et al. 2000) and is also caused by degeneration of the nephric duct during mesonephros development (data not shown). In summary, the analysis of compound Pax2,Pax8 mutant embryos unequivocally demonstrated that the transcription factors Pax2 and Pax8 cooperatively control the development of the urogenital system.

\section{Pax2-independent initiation and maintenance of Pax8 expression during early kidney development}

To better understand the cooperation of Pax 2 and Pax 8 in kidney patterning, we investigated the early expression pattern of the two Pax genes during pro- and mesonephros development by whole-mount in situ hybridization. Pax2 expression was initiated at the 8-9-somite stage in the intermediate mesoderm corresponding to the pronephric anlage (Fig. 3A). The expression of Pax8 was detected even earlier at the 6-7-somite stage in the same region of the intermediate mesoderm (Fig. 3B). Therefore, these data identify $\operatorname{Pax} 8$ as the earliest known marker of mouse pronephros development in analogy to our previous finding that $\operatorname{Pax} 8$ is the earliest gene to be expressed in the developing kidney of zebrafish embryos (Pfeffer et al. 1998). Moreover, the Pax2 and Pax8 genes were coexpressed in the pronephric anlage, as shown by double staining of 10-somite embryos (Fig. 3C). At the same stage, the Pax2/8-positive cells in the intermediate mesoderm did not yet express the epithelial marker laminin, indicating that these cells have not yet undergone the mesenchymal-epithelial transition leading to the formation of the pronephros (Fig. 3D).

Pax2 is known to cross-regulate the Pax8 gene during midbrain-hindbrain boundary development (Ye et al. 


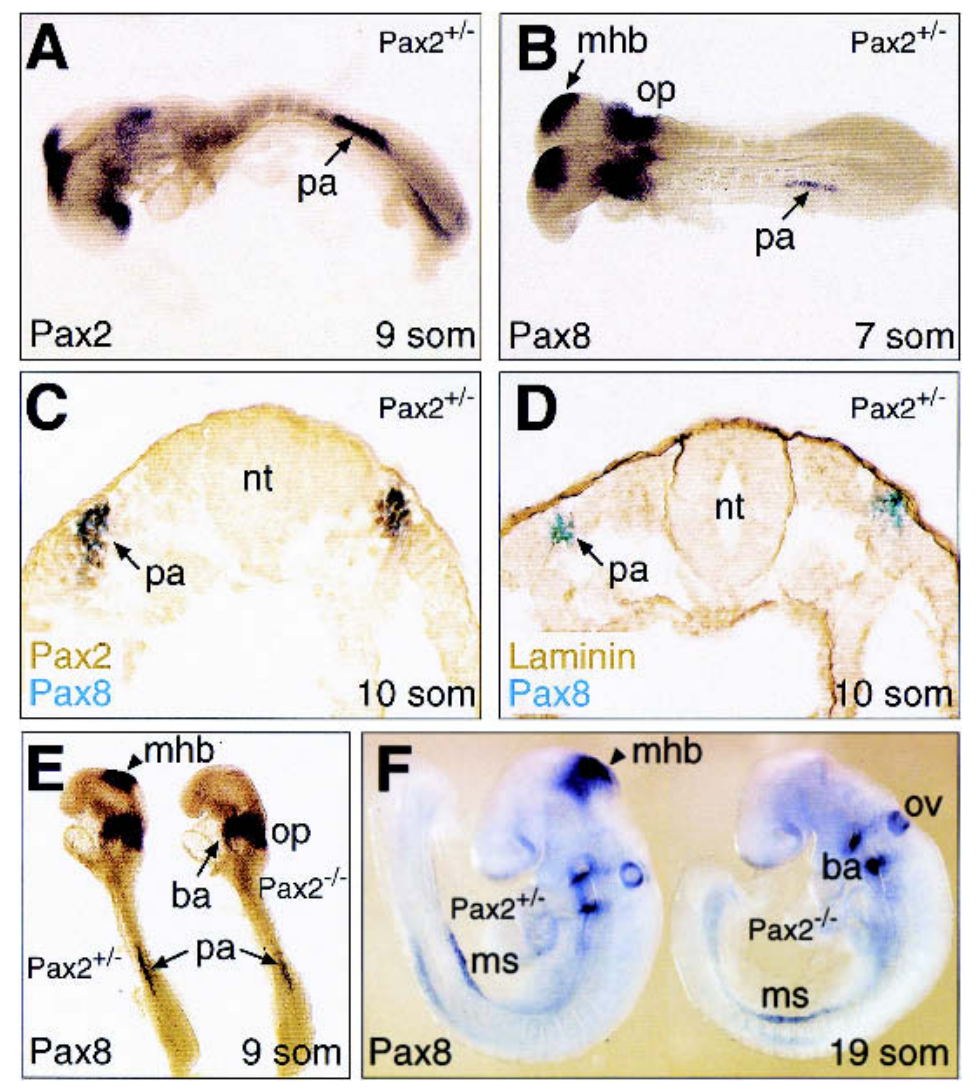

Figure 3. Pax2-independent expression of $\operatorname{Pax} 8$ at the onset of kidney development. $(A, B)$ Initiation of $\mathrm{Pax}$ gene expression in the pronephric anlage of $\mathrm{Pax}^{+/-} \mathrm{em}-$ bryos. As shown by whole-mount in situ hybridization, Pax8 expression $(B)$ was first detected at the 7 -somite stage in the intermediate mesoderm at the level of the fifth and sixth somites corresponding to the pronephric anlage. At the 9-somite stage, the Pax2 gene $(A)$ was also expressed in the pronephric anlage, where its expression was first observed at 8 somites (data not shown). (C) Coexpression of $P a x 2$ and $P a x 8$ in the pronephric anlage. Pax2 protein (brown) and Pax 8 transcripts (blue) were simultaneously detected on a transverse section of a 10 -somite $\mathrm{Pax}^{+/-}$embryo by immunostaining and in situ hybridization, respectively. $(D)$ Absence of epithelial cells in the pronephric anlage at 10 somites. An adjacent section of the same embryo shown in $(C)$ was stained with an anti-laminin antibody (brown) in combination with Pax8 in situ hybridization (blue). (E,F) Pax2-independent initiation and maintenance of Pax8 expression during kidney development. Pax8 transcripts were detected by whole-mount in situ hybridization of $\mathrm{Pax}^{+/-}$and $\mathrm{Pax2}^{-/-}$embryos at $9(E)$ and $19(F)$ somites. ba, branchial arch; mhb, midbrainhindbrain boundary; ms, mesonephros; $\mathrm{nt}$, neural tube; op, otic placode; ov, otic vesicle; pa, pronephric anlage; som, somite.
2001; Fig. 3E). In contrast, the initiation of $\operatorname{Pax} 8$ expression in the pronephric anlage occurred independently of Pax2, as shown by in situ hybridization analysis of Pax2 $2^{-/-}$embryos (Fig. 3E). The absence of Pax2 did also not affect the maintenance of $\operatorname{Pax} 8$ expression during mesonephros formation (Fig. 3F). Conversely, the kidney-specific expression of $\operatorname{Pax} 2$ must be independent of Pax8, as kidney morphogenesis is entirely normal in $\mathrm{Pax}^{-/-}$mice (Fig. 2B) in contrast with $\mathrm{Pax}^{-/-}$mice (Torres et al. 1995; Favor et al. 1996). We conclude, therefore, that the $P a x 2$ and $P a x 8$ genes are regulated independently of each other during early kidney development.

\section{Absence of pro- and mesonephros development in $\mathrm{Pax}^{-/-} \mathrm{Pax} 8^{-/-}$embryos}

The formation of a normal mesonephros in $\mathrm{Pax}^{-/-} \mathrm{em}-$ bryos (Torres et al. 1995) suggests that the early and Pax2-independent expression of $\operatorname{Pax} 8$ may compensate for the loss of Pax2 at the onset of kidney development. To test this hypothesis, we analyzed the formation of the pro- and mesonephros in $\mathrm{Pax} 2^{-/-} \mathrm{Pax}^{-/-}$embryos. As the mutant $\mathrm{Pax}^{-}$allele contained an in-frame lacZ gene insertion in the Pax2 locus (Bouchard et al. 2000), we used the expression of $\beta$-galactosidase as a kidney-specific marker to visualized the pro- and mesonephros. At the 15 -somite stage, the $\beta$-galactosidase expression domain extended from the ninth somite to just beyond the last forming somite in the intermediate mesoderm of $\mathrm{Pax}^{+/-}$ or Pax $2^{-/-}$embryos (Fig. 4A,B). This domain corresponds to the pronephros and newly forming mesonephros with its caudally extending nephric duct (Fig. 4A,B). Strong $\beta$-galactosidase expression in this region was still observed in the presence of a single wild-type Pax8 allele in Pax $2^{-/-} \mathrm{Pax} 8^{+/-}$embryos (Fig. 4C). In contrast, only weak $\beta$-galactosidase activity could be detected in the intermediate mesoderm of $\mathrm{Pax}^{-/-} \mathrm{Pax}^{-/-}$embryos, indicating that the pro- and mesonephros failed to properly form in the absence of any $\operatorname{Pax} 2 / 8$ protein.

The onset of pronephros formation is characterized by the mesenchymal-epithelial transition of specific mesodermal cells, which leads to the formation of the nephric duct (Saxén 1987). We therefore investigated the developmental defect in $\mathrm{Pax}^{-/-} \mathrm{Pax} 8^{-/-}$embryos by analyzing the expression of the epithelial marker laminin in the intermediate mesoderm. Although laminin expression was not yet observed at 10 somites (Fig. 3D), a stripe of laminin-positive cells could be detected at 12 somites in the intermediate mesoderm of "control" $\mathrm{Pax}^{-/-} \mathrm{em}$ bryos (Fig. 5A). Later, at the 20-somite stage, laminin expression was detected in a ring consisting of the basement membranes of the nephric duct in all embryos that carried at least one functional Pax2/8 allele (Fig. 5C-E). In marked contrast, laminin expression was detected neither at the 12- nor 20-somite stage in the intermediate mesoderm of $\mathrm{Pax}^{-/-} \mathrm{Pax}^{-/-}$embryos (Fig. 5B,F). Moreover, E-cadherin, a second epithelial marker, was 
Figure 4. Early defects of pro- and mesonephros development in $\mathrm{Pax}^{-/-} \mathrm{Pax}^{-/-}$embryos. $(A-D)$ The expression of $\beta$-galactosidase from the mutant Pax2 $^{-}$allele (Bouchard et al. 2000) was used as a kidney-specific marker to visualize pro- and mesonephros development in Pax2,Pax8 mutant embryos of the indicated genotypes. Embryos of the same litter, which developed to the $14-(C, D)$ or 15$(A, B)$ somite stage, were stained with X-gal for the same period of time (15 h). $\operatorname{Pax} 2^{+/-}(A)$ and $\mathrm{Pax}^{-/-}$ $(B)$ embryos expressed $\beta$-galactosidase activity in the pronephros (pn) and mesonephros (ms) extending from somite 9 to just beyond the last somite, 15. The $\beta$-galactosidase expression in $\mathrm{Pax}^{-1}$ $-\mathrm{Pax}^{+/-}$embryos $(C)$ was restricted to a region between somites 9 and 13 . The absence of any functional $\mathrm{Pax} 2 / 8$ allele led to the down-regulation of $\beta$-galactosidase expression (arrowheads) in $\mathrm{Pax}^{-1}$ -Pax $8^{-/-}$embryos $(D)$. It is important to note that the presence of a single $\mathrm{Pax}^{-}$(lacZ) allele resulted in a disproportionately lower X-gal staining signal in $\mathrm{Pax}^{+/-}$embryos $(A)$ compared with $\mathrm{Pax}^{-/-}$embryos $(B, C)$, which expressed the lac $Z$ gene only at

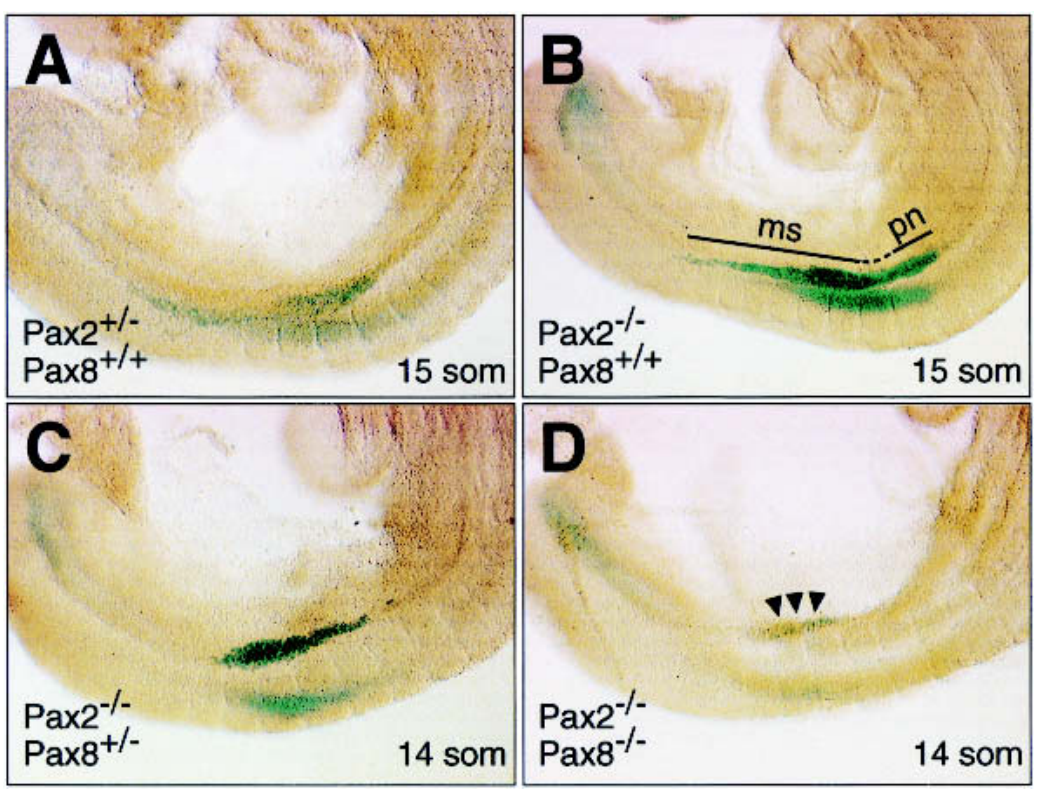
a twofold higher level because of the presence of two lac $Z$ alleles. This nonlinearity of the $\beta$-galactosidase assay is also the reason why the reduced lacZ expression in $\mathrm{Pax} 2^{-/-} \mathrm{Pax}^{-/-}$embryos $(D)$ generated a low X-gal staining signal, although it could be readily detected by the more sensitive, but nonquantitative antibody staining method (Fig. $6 \mathrm{H}$ ).

expressed near the luminal surface of the nephric duct in $\mathrm{Pax}^{+/-}$and $\mathrm{Pax2}^{-/-}$embryos at 20 somites (Fig. 5C,D). Although E-cadherin expression was already reduced by lowering the Pax protein dose in $\mathrm{Pax}^{+/-} \mathrm{Pax}^{-/-}$embryos (Fig. 5E), it was never detected in the intermediate mesoderm of $\mathrm{Pax}^{-/-} \mathrm{Pax}^{-/-}$embryos (Fig. 5F). We conclude therefore that Pax2 and Pax 8 together control the onset of pronephros development by regulating the mesenchymal-epithelial transition of intermediate mesoderm cells.

\section{Absence of nephric gene expression in $\mathrm{Pax}^{-/-} \mathrm{Pax} 8^{-/-}$embryos}

We next examined the expression of early kidney-specific genes in Pax2,Pax8 double-mutant embryos. The c-ret gene is one of the first genes to be specifically expressed in the nephric duct of the pro- and mesonephros (Pachnis et al. 1993). At 12 somites, high c-ret expression was detected at the caudal end of the pronephros adjacent to the last forming somite in wild-type embryos (Fig. 6A). In contrast, the $\mathrm{Pax} 2^{-/-} \mathrm{Pax} 8^{-/-}$embryos entirely failed to express the $c$-ret gene in the intermediate mesoderm at this early stage (Fig. 6B) as well as at 20 somites (data not shown). The Lim1 gene is initially transcribed throughout the lateral mesoderm (Barnes et al. 1994; Fujii et al. 1994; Tsang et al. 2000), as shown by its expression in the lateral plate mesoderm, intermediate mesoderm, and genital ridge at the 12 -somite stage (Fig. 6C). At this early time point, Lim 1 is coexpressed with Pax2 or $\beta$-galactosidase in the pronephric anlage of control or $\mathrm{Pax}^{-/-} \mathrm{Pax}^{-/-}$embryos, respectively (Fig. $6 \mathrm{C}, \mathrm{D})$. Thereafter, the broad Lim1 expression becomes restricted to the mesonephric duct at 20 somites (Fig. 6E) and is subsequently also observed in the condensing mesenchyme and nephric tubules (Barnes et al. 1994; Fujii et al. 1994; Tsang et al. 2000). At 20 somites, Lim1 expression could, however, not be detected in the intermediate mesoderm of $\mathrm{Pax}^{-/-} \mathrm{Pax}^{-/-}$embryos (Fig. 6F). In contrast, $\beta$-galactosidase-positive cells were readily identified in double-mutant embryos both at 12 and 20 somites (Fig. 6D,H). Therefore, the lack of c-ret and Lim1 expression at these early stages was not caused by a selective loss of intermediate mesoderm cells, but rather indicates a complete failure of pro- and mesonephros formation in the combined absence of Pax2 and Pax8.

At 20 somites, the nephrogenic mesenchyme has just started to condense to form the tubules of the mesonephros in a process that is initiated by signals from the nephric duct (Saxén 1987). We have visualized this process by double staining of control $\mathrm{Pax}^{+/-}$embryos for $\beta$-galactosidase (Pax2) and WT1 expression, as the WT1 gene is expressed in the intermediate mesoderm and genital ridge (Fig. 6I) and Pax2 ( $\beta$-Gal) in the nephric duct and condensing mesenchyme (Fig. 6I). Three distinct cell populations could be visualized in control $\mathrm{Pax}^{+/-}$embryos by this procedure: the $\mathrm{WT}^{-} \beta-\mathrm{Gal}^{+}$nephric duct (red), the $\mathrm{WT}^{+} \beta-\mathrm{Gal}^{+}$condensing mesenchyme (yellow), and the $\mathrm{WT}^{+} \beta-\mathrm{Gal}^{-}$genital ridge and intermediate mesoderm (green; Fig. 6I). Although $\mathrm{WT}^{-} \beta-\mathrm{Gal}^{+}$(red) and $\mathrm{WT}^{+} \beta-\mathrm{Gal}^{+}$(yellow) cells were also present in $\mathrm{Pax}^{-/-} \mathrm{Pax}^{-/-}$embryos, they were intermingled without any apparent patterning (Fig. $6 \mathrm{~K}$ ), indicating that these cells neither formed a nephric duct nor condensing mesenchyme in the absence of Pax2 and Pax8. Therefore, the lack of kidney-specific gene expression and nephric structures in $\mathrm{Pax}^{-/-} \mathrm{Pax}^{-{ }^{--}}$embryos points to an essen- 

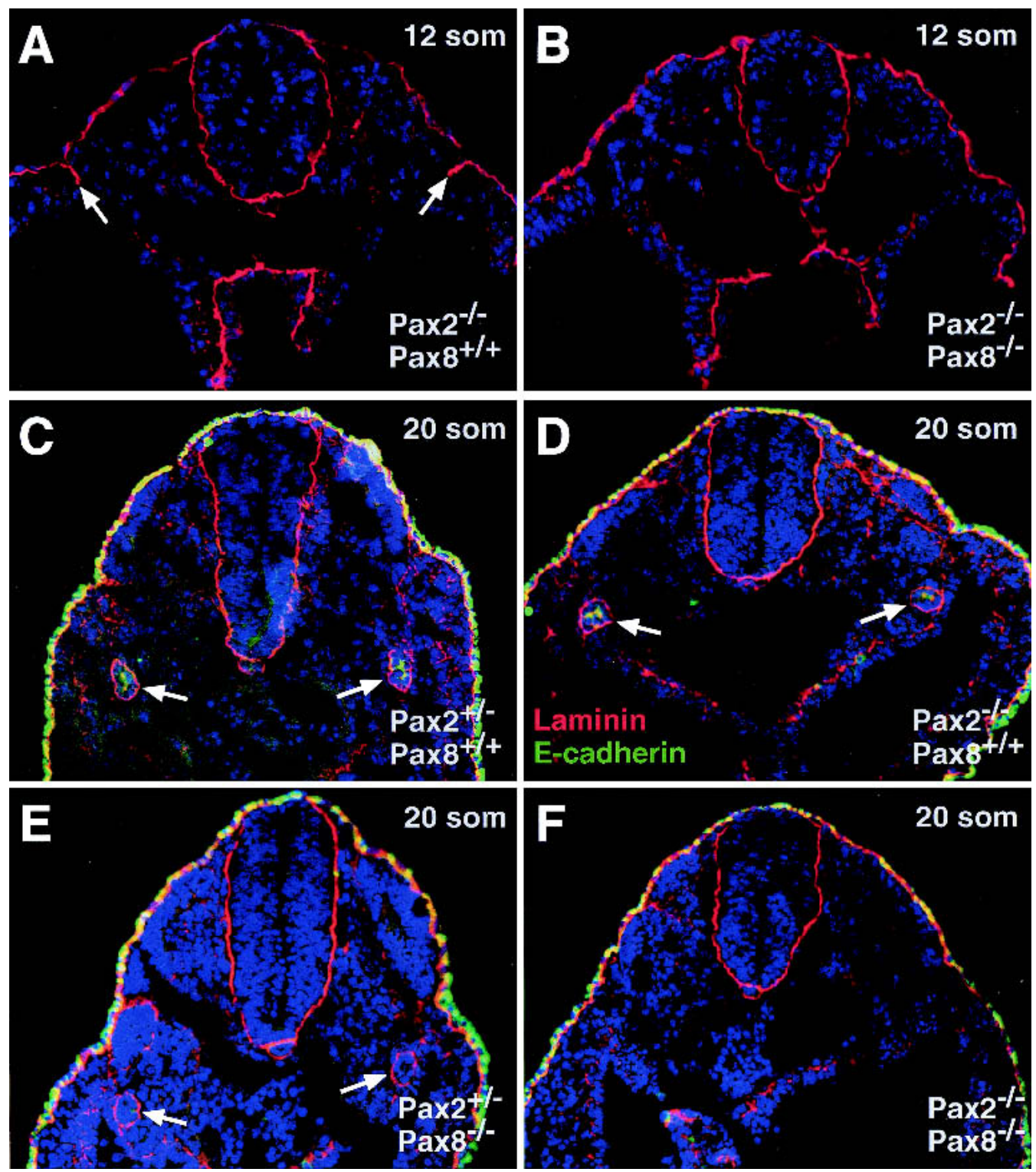

Figure 5. Absence of mesenchymal-epithelial transitions in the intermediate mesoderm of $\mathrm{Pax}^{-{ }^{-}} \mathrm{Pax} 8^{-{ }^{-}}$embryos. The expression of the epithelial markers laminin (red) and E-cadherin (green) was analyzed in embryos of the indicated genotypes at $12(A, B)$ or $20(C-F)$ somites by immunostaining of transverse sections. At 12 somites, epithelial cells were bilaterally present in the pronephric region of $\mathrm{Pax}^{-/-} \mathrm{Pax} 8^{+/+}$embryos (arrows in $A$ ) in contrast with $\mathrm{Pax}^{-/-} \mathrm{Pax} 8^{-/-}$embryos $(B)$. At the 20 -somite stage, a distinct ring of laminin expression demarcates the nephric duct of all mutant embryos (arrows in $C-E$ ) except in $P a x 2^{-/-}$Pax $8^{-/-}$embryos $(F)$. E-cadherin expression was reduced in the nephric duct of $\mathrm{Pax}^{+/-} \mathrm{Pax}^{-/-}$embryos $\left(E\right.$; additional data not shown) and absent in $\mathrm{Pax} 2^{-/-} \mathrm{Pax} 8^{-/-}$ embryos $(F)$.

tial role of Pax2 and Pax8 in committing mesodermal cells to the kidney fate.

Late apoptosis of mesodermal cells in the absence of nephric induction

Several studies have implicated Pax2 in the control of cell survival during metanephros development (Bouchard et al. 2000; Ostrom et al. 2000; Porteous et al. 2000; Torban et al. 2000). We therefore assessed by combined TUNEL and Pax2 ( $\beta$-Gal) staining whether in- creased apoptosis may also contribute to the early kidney developmental defects in $\mathrm{Pax}^{-/-} \mathrm{Pax}^{-{ }^{-}}$embryos. No apoptotic cells could be detected, however, within or near the Pax2 ( $\beta$-Gal) expression domain in the intermediate mesoderm of control and $\mathrm{Pax}^{-/-} \mathrm{Pax}^{-/-}$embryos at the 12 -somite stage (Fig. 7A,B), when the pronephros just starts to form in wild-type embryos (Fig. 5A). At 20 somites, a slight increase in apoptotic cells was observed in $\mathrm{Pax}^{-/-} \mathrm{Pax}^{-/-}$embryos (Fig. 7C,D), whereas apoptosis was massively induced in these embryos at 25 somites (Fig. 7E,F). In the absence of Pax2 and Pax8, al- 


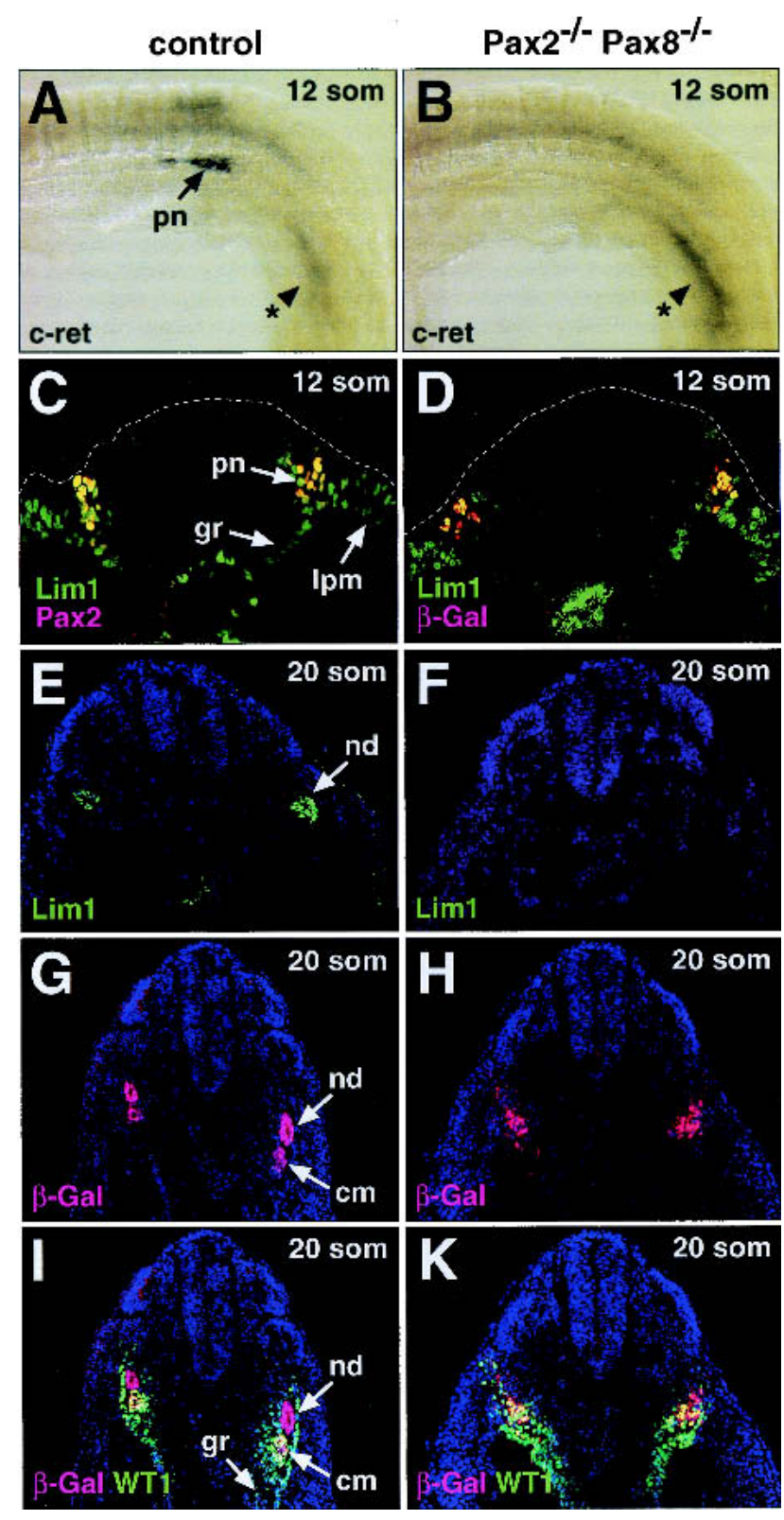

Figure 6. Absence of Lim1 and c-Ret expression in the intermediate mesoderm of $\mathrm{Pax}^{-/-} \mathrm{Pax}^{-/-}$embryos. $(A-D) \mathrm{c}$-Ret and Lim1 expression at the 12-somite stage. $c$-Ret transcripts were detected by whole-mount in situ hybridization in the pronephros of wild-type control embryos $(A)$ in contrast to Pax $2^{-1-} \mathrm{Pax}^{-/-}$embryos $(B)$ that, however, still expressed $c$-ret in the tail region (indicated by asterisk). Antibody staining of transverse sections was used to reveal the expression of Lim1 and Pax 2 or $\beta$-galactosidase $\left(\beta\right.$-Gal) in control $\mathrm{Pax}^{+/-}(C)$ and Pax2 ${ }^{-1-}$ Pax $^{-1-}(D)$ embryos, respectively. $(E-K)$ Lim1 and WT1 expression at the 20-somite stage. Adjacent transverse sections of control $\mathrm{Pax}^{+/-}$and $\mathrm{Pax} 2^{-/-} \mathrm{Pax} \mathrm{O}^{-/-}$embryos were analyzed by immunostaining for $\operatorname{Lim} 1(E, F), \beta-\mathrm{Gal}(G-K)$ and $\mathrm{WT} 1(I, K)$ protein expression. $\mathrm{cm}$, condensing mesenchyme; gr, genital ridge; lpm, lateral plate mesoderm; nd, nephric duct; pn, pronephros.

most all $\beta$-galactosidase-positive cells were undergoing apoptosis (Fig. 7F) in striking contrast with control em- bryos, where apoptotic cells could hardly be detected in the mesonephros and surrounding mesoderm at 25 somites (Fig. 7E). Interestingly, $\sim 20 \%$ of the apoptotic signals in $\mathrm{Pax}^{-/-} \mathrm{Pax}^{-/-}$embryos were observed outside of the $\beta$-galactosidase expression domain (Fig. 7D,F), thereby raising the possibility that Pax 2 and Pax 8 may control the survival of adjacent mesodermal cells by a non-cell-autonomous mechanism. Importantly, however, the cells of the intermediate mesoderm continued to proliferate normally during early kidney development even in the absence of Pax 2 and $\operatorname{Pax} 8$ (data not shown). Together, these data indicate that a relatively long time period $(-24 \mathrm{~h})$ elapses from the onset of $\mathrm{Pax} 2 / 8$ expression (at 6-8 somites) to the activation of fulminant apoptosis (at 25 somites) in $\mathrm{Pax}^{-/-} \mathrm{Pax}^{-/-}$embryos. This late induction of apoptosis therefore points to a more indirect role of Pax 2 and Pax 8 in controlling the survival of intermediate mesoderm cells. Importantly, the loss of intermediate mesoderm cells did not affect normal development of the gonads and limbs in $\mathrm{Pax}^{-/-} \mathrm{Pax}^{-/-}$embryos (data not shown).

\section{Ectopic kidney formation by Pax2 misexpression}

So far we have shown by loss-of-function analysis in mouse embryos that Pax 2 and Pax 8 are necessary for proand mesonephros development. We next performed gainof-function experiments in chick embryos to investigate whether Pax 2 expression is also sufficient to promote early kidney development. To this end, a replicationcompetent retrovirus expressing the mouse Pax $2 \mathrm{~b}$ protein (RCAS-mPax2) was unilaterally injected at $\mathrm{HH}$ stages 4-6 into the mid-streak tissue of chick embryos, which subsequently gave rise, among other tissues, to the intermediate mesoderm. Two days after injection, the nephric structures were visualized by analyzing the kidney-specific expression of c-ret, Lim1, laminin, and Pax2 (Fig. 8). The formation of an ectopic nephric duct with its associated condensing mesenchyme was observed in $19 \%(n=13)$ of 70 embryos that survived the injection of the RCAS-mPax2 virus (Fig. 8). The ectopic nephric duct developed in a mirror image-like fashion in the region of the genital ridge (Fig. 8) or intermediate mesoderm (data not shown) and extended on average for a length of $50-150 \mu \mathrm{m}$, as shown by serial sectioning. Importantly, we could never detect any ectopic nephric structures in embryos $(n=32)$ that were injected with the control virus RCAS-AP (Fekete and Cepko 1993; data not shown). We therefore conclude that the Pax $2 / 8$ proteins are not only necessary, but also sufficient for committing mesodermal cells to the nephric lineage.

\section{Discussion}

Although a large number of genes have been identified as regulators of kidney organogenesis, targeted mutagenesis has failed to demonstrate an essential role for any of these genes in controlling the earliest steps of kidney development, that is, the formation of the pro- and me- 

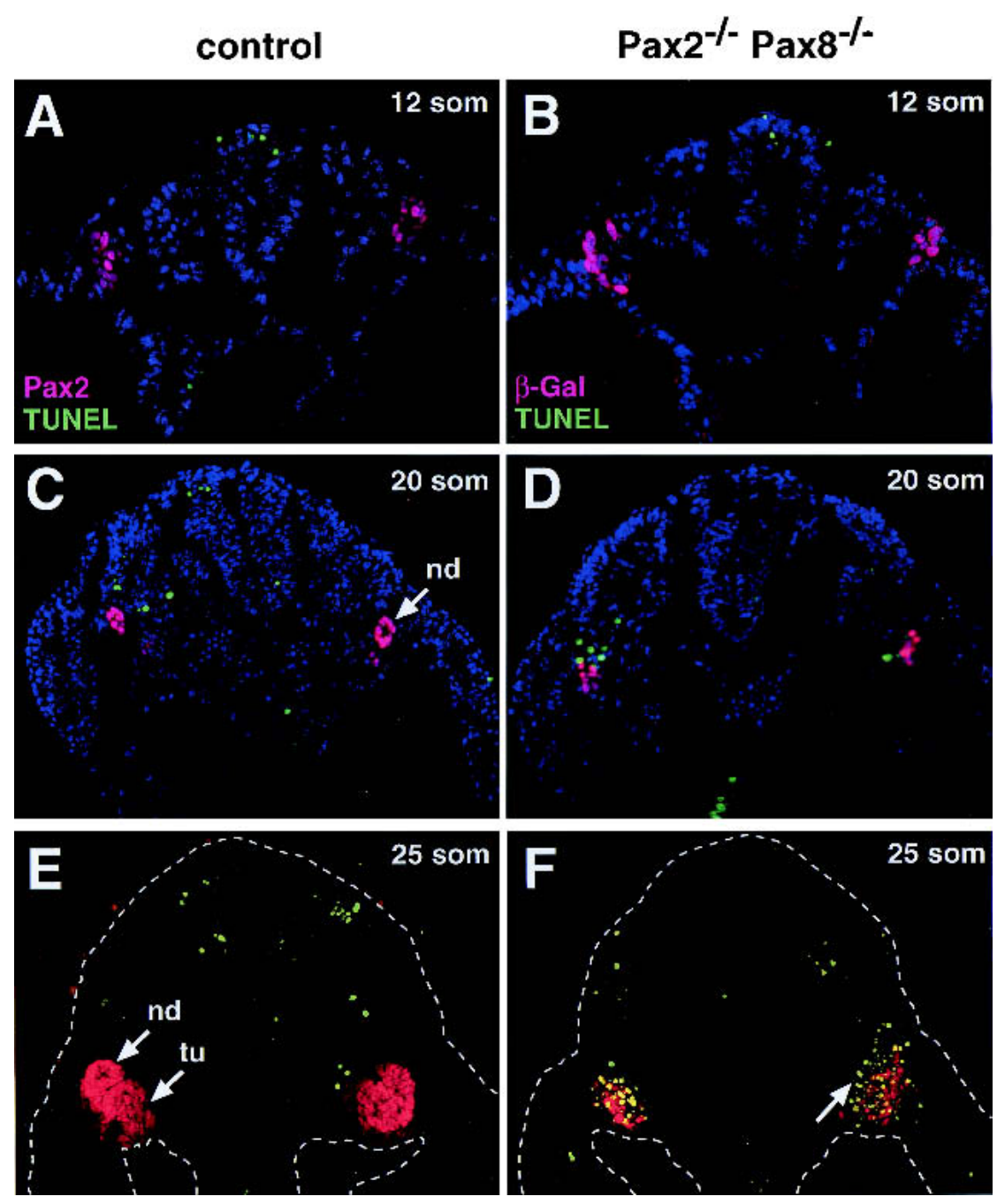

Figure 7. Late apoptosis of intermediate mesoderm cells in $\mathrm{Pax}^{-/-} \mathrm{Pax}^{-/-} \mathrm{em}$ bryos. Cells undergoing apoptosis (green dots) were detected on transverse sections of control or $\mathrm{Pax}^{-/-} \mathrm{Pax}^{-/-}$embryos by TUNEL assay in combination with immunohistochemical analysis of Pax2 (red; $A, C, E)$ or $\beta$-galactosidase $(\operatorname{red}, B, D, F)$ expression. Apoptotic cells within or adjacent to the $\beta$-Gal (Pax2) expression domain were absent in $\mathrm{Pax}^{-1-} \mathrm{Pax} 8^{-/}$embryos at 12 somites $(B)$, slightly increased at 20 somites $(D)$ and abundant at 25 somites $(F)$ compared with the control $\mathrm{Pax2}^{+/-}(C)$ and $\mathrm{Pax}^{+/-}(A, E)$ embryos. An arrow in $F$ points to apoptotic cells surrounding the $\beta$-Gal expression domain. nd, nephric duct; tu, tubules. sonephros (Davies and Brändli 2002). Most notably, mutation of the Pax2 gene interfered with metanephros development (Torres et al. 1995; Favor et al. 1996), whereas kidney morphogenesis was entirely normal in Pax8-deficient mice (Mansouri et al. 1998). Here we demonstrate that $P a x 2$ and $P a x 8$ have redundant functions in kidney organogenesis in agreement with the fact that members of the Pax2/5/8 family can substitute for each other in mouse development because of their equivalent transcriptional activity (Bouchard et al. 2000). Pax2 and Pax8 are not only coexpressed at the onset of kidney development, but together are also required for the formation of the pro- and mesonephros. In the absence of both transcription factors, the intermediate mesoderm was unable to undergo the mesenchymal-epithelial transition necessary for nephric duct formation and failed to express early markers of nephric identity such as c-Ret and Lim1. Conversely, misexpression of Pax2 was sufficient to induce ectopic nephric structures in the intermediate mesoderm and genital ridge. Therefore, both gain- and loss-of-function analyses identified $\operatorname{Pax} 2$ and $\operatorname{Pax} 8$ as critical regulators of nephric lineage specification.

The first morphological sign of pronephros develop- ment is the conversion of mesenchymal cells in the intermediate mesoderm to epithelial cells developing into the pronephric duct (Saxén 1987). This initial step of kidney development completely failed in $\operatorname{Pax} 2, \operatorname{Pax} 8$ double-mutant embryos, thereby preventing the formation of the nephric duct and its associated tubules. Pax2 also has an important role in controlling mesenchymalepithelial transitions during adult kidney morphogenesis, as the inhibition of Pax 2 expression by antisense oligonucleotides prevented the condensation and epithelial conversion of mesenchymal cells in mouse kidney organ cultures (Rothenpieler and Dressler 1993). Likewise, the epithelial differentiation of the pronephric duct was abnormal in Pax2.1-deficient (noi) zebrafish embryos (Majumdar et al. 2000). Therefore, the Pax $2 / 8$ proteins appear to control the gene expression program responsible for mesenchymal-epithelial conversion not only at the onset but also throughout kidney development.

A striking, but late aspect of the $\operatorname{Pax} 2, \operatorname{Pax} 8$ doublemutant phenotype was the fulminant apoptosis of the intermediate mesoderm in 25-somite embryos (E9.5). In agreement with this, Pax2 has been implicated previ- 

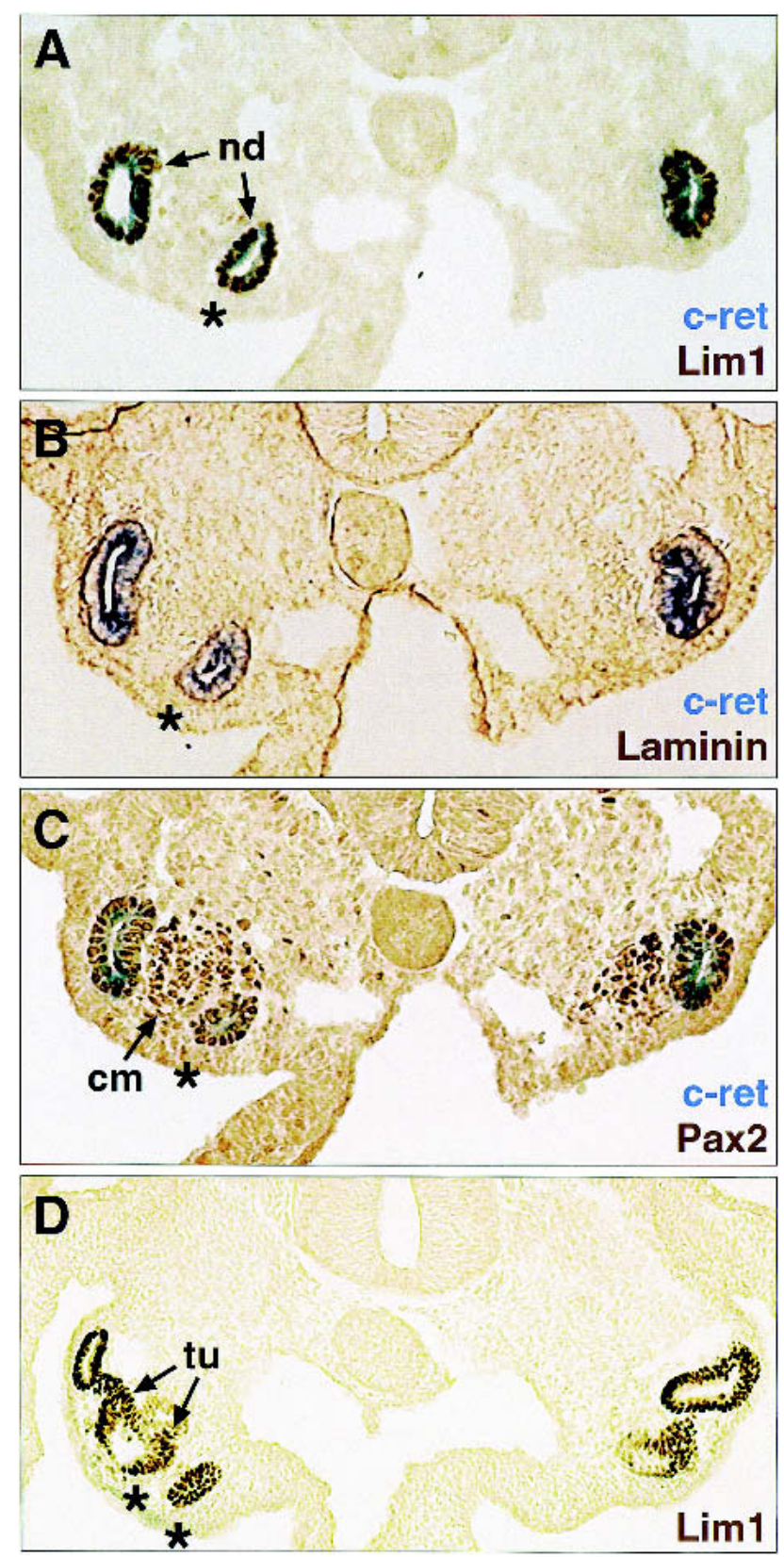

Figure 8. Ectopic kidney formation on Pax 2 misexpression in the intermediate mesoderm. A chicken retrovirus expressing the mouse Pax 2 protein (RCAS-mPax2) was injected into the mid-streak tissue adjacent to Hensen's node on one side of chick embryos at $\mathrm{HH}$ stage 4-6. $(A-C)$ Ectopic kidney formation in a representative embryo at $48 \mathrm{~h}$ after injection (HH stage 17-18). Adjacent sections were stained by in situ hybridization for $c$-ret mRNA expression (blue; $A-C$ ) and by immunohistochemistry (brown) for Lim1 $(A)$, laminin $(B)$ or Pax2 $(C)$ protein expression. (D) Lim1 staining of an embryo that progressed further in kidney development. Asterisks denote ectopic nephric ducts and tubules that formed in the region of the genital ridge on the injected side $(l e f t) . \mathrm{cm}$, condensing mesenchyme; nd, nephric duct; tu, tubules.

ously in the survival control of nephric cells, as its twofold reduced expression in $\mathrm{Pax}^{+/-}$embryos led to a mod- erate increase in apoptosis during metanephros development (Bouchard et al. 2000; Ostrom et al. 2000; Porteous et al. 2000). In contrast, the complete absence of Pax2 and Pax 8 resulted in the death of all $\beta$-galactosidase-positive cells in the intermediate mesoderm, although this process was delayed by $\sim 24 \mathrm{~h}$ compared with the initiation of Pax2 ( $\beta$-Gal) and Pax8 expression in the pronephric anlage at 6-8 somites. Interestingly, the region undergoing cell death extended beyond the domain of Pax2 ( $\beta$-Gal) expression, indicating that the Pax $2 / 8$ proteins control the survival of the adjacent mesoderm in an noncell-autonomous manner. Candidates for such a noncell-autonomous signal could be secreted molecules of the EGF, FGF, or BMP families, which are known to maintain the survival of the nephrogenic mesenchyme (Coles et al. 1993; Perantoni et al. 1995; Godin et al. 1998; Dudley et al. 1999).

As each Pax protein fulfills multiple roles in development, it is able to initiate an organ-specific gene expression program only in cooperation with local transcription factors (Bouchard et al. 2003). Misexpression of Pax5 throughout the entire hematopoietic system was able to bias lineage commitment toward the B cell pathway only within the lymphoid progenitor cell compartment (Souabni et al. 2002). Similarly, the kidney-inducing potential of Pax 2 was temporally and spatially restricted, as the Pax2 retrovirus had to be delivered to the lateral mesoderm before somitogenesis and could then induce ectopic kidneys only in a competence region corresponding to the intermediate mesoderm and genital ridge (data not shown). Homeodomain transcription factors of the Lim protein family are likely cofactors that cooperate with the Pax $2 / 8$ proteins in the specification of the nephric lineage. During early somitogenesis, the $\operatorname{Lim} 1$ gene is expressed throughout the lateral mesoderm including the genital ridge and intermediate mesoderm (Barnes et al. 1994; Fujii et al. 1994; Tsang et al. 2000) and is initially expressed in the pronephric anlage independently of Pax2 and Pax8. Thereafter, the widespread Lim1 expression is rapidly restricted to the nephrogenic cord (Barnes et al. 1994; Fujii et al. 1994; Tsang et al. 2000), where it overlaps with and becomes dependent on Pax2 and Pax8. Importantly, enforced expression of Lim1 or Pax8 alone was able to induce ectopic pronephric structures only at a low frequency in Xenopus embryos (Carroll and Vize 1999). In contrast, ectopic expression of Lim1 together with Pax8 synergistically activated pronephros development in frog embryos (Carroll and Vize 1999|. This finding, together with our data, suggests that Lim1 acts as a competence factor to determine the nephric field, within which the local induction of Pax2 and Pax8 specifies the kidney fate.

To date, little is known about Pax2/8 target genes that mediate the function of these two transcription factors during early kidney development. One of them codes for the secreted molecule GDNF (Brophy et al. 2001), which is essential for normal morphogenesis of the adult kidney (Moore et al. 1996; Pichel et al. 1996; Sánchez et al. 1996). Interestingly, the expression of c-Ret, the signaling receptor for GDNF, was never initiated in the inter- 
mediate mesoderm of $\mathrm{Pax}^{-/-} \mathrm{Pax} 8^{-/-}$embryos, suggesting that the GDNF-Ret pathway is regulated at multiple levels by the Pax $2 / 8$ proteins. GDNF signaling proved to be sufficient for guiding the caudal migration of the pronephric duct in Axolotl embryos (Drawbridge et al. 2000), consistent with the early expression of c-ret during kidney development (Pachnis et al. 1993). In contrast, targeted mutagenesis in the mouse embryo has identified only a later role of the GDNF-Ret signaling pathway in controlling the outgrowth and branching of the ureter during metanephros development (Schuchardt et al. 1994; Moore et al. 1996; Pichel et al. 1996; Sánchez et al. 1996).

The role of Pax2 and Pax8 in nephric lineage specification appears to be conserved in vertebrate evolution, as these two genes are expressed as the earliest kidney-specific markers in the intermediate mesoderm during mouse, frog, and zebrafish development (Fig. 3; Pfeffer et al. 1998; Heller and Brändli 1999). Moreover, the mutually independent initiation of $\operatorname{Pax} 2$ and $P a x 8$ expression in the pronephric anlage has also been conserved between mouse and zebrafish (Fig. 3; Pfeffer et al. 1998), indicating that the two genes respond to the same signals from the surrounding tissue. Using microsurgical manipulation of the chick embryo, Obara-Ishihara et al. (1999) identified the surface ectoderm as the source of a BMP4 signal that activates Pax2 expression and pronephros development in the underlying intermediate mesoderm. The study of Mauch et al. (2000) demonstrated that yet unidentified signals from the paraxial mesoderm are both necessary and sufficient for Pax2 activation and pronephros induction. Based on these data, it is conceivable that signals emanating from perpendicular sources (ectoderm vs. somite) may induce at their intersection the expression of Pax2 and Pax8 in a discrete group of mesodermal cells. As the specification of the nephric lineage is a direct consequence of the initiation of $\mathrm{Pax} 2 / 8$ expression (as shown by this study), it will be important to gain molecular insight into the regulation of these two genes by identifying their essential kidney-specific enhancers and upstream regulatory factors, using transgenic approaches (Pfeffer et al. 2002).

The functional analyses of other Pax genes have revealed a fundamental role for this class of transcription factors in cell lineage specification during organ development (for review, see Bouchard et al. 2003). For instance, Pax 5 is essential for the formation of B-lymphocytes within the hematopoietic system (Nutt et al. 1999), Pax8 for follicular cells in the thyroid gland (Mansouri et al. 1998), Pax4 for insulin-producing $\beta$-cells, and somatostatin-expressing $\delta$-cells in the endocrine pancreas (Sosa-Pineda et al. 1997), Pax6 for the glucagonsynthesizing $\alpha$-cells (St-Onge et al. 1997; Sander et al. 1997), and Pax7 for myogenic progenitor (satellite) cells in adult skeletal muscle (Seale et al. 2000). The specification of the nephric lineage by Pax 2 and Pax 8 is therefore consistent with the more general role of Pax proteins in cell fate determination during organogenesis. It will be interesting to see whether Pax2 and Pax8 restrict the fate of the mesodermal progenitor cells to the neph- ric lineage by simultaneously activating the expression of kidney-specific genes and repressing the transcriptional program of alternative cell lineages similar to the role of Pax5 in B cell commitment (Nutt et al. 1999).

\section{Materials and methods}

\section{Generation of Pax8 mutant mice}

The Pax8 targeting vector was assembled in a pSP64 plasmid containing a polylinker with appropriate restriction sites. A 1.6$\mathrm{kb} S s p \mathrm{I}-\mathrm{NcoI}$ fragment (partially digested with NcoI; intron 2) and a $3.8-\mathrm{kb}$ SacI-XbaI fragment (exon 4-7) were cloned as $5^{\prime}$ and $3^{\prime}$ homology regions from a mouse Pax 8 cosmid into the modified pSP64 vector. The cre gene was inserted as a $1.1-\mathrm{kb}$ EarI-MluI fragment from pMC-Cre by the use of an adaptor sequence restoring the Pax8 reading frame at the $\mathrm{NcoI}$ site in exon 3. A 1.9-kb SacI-SalI DNA fragment containing the PGKneo expression cassette (flanked by frt sites) from pM30 (Meyers et al. 1998) was cloned downstream of the cre gene, whereas the $H S V$-tk and DT-A genes (negative selection) were inserted upstream of the $5^{\prime}$ homology region. NotI-linearized DNA (15 $\left.\mu \mathrm{g}\right)$ was electroporated into E14.1 ES cells $\left(1 \times 10^{7}\right)$ followed by selection with $250 \mu \mathrm{g} / \mathrm{mL}$ G418 and $2 \mu \mathrm{M}$ gancyclovir. Individual clones were screened for homologous recombination by nested $\mathrm{PCR}$, and positive clones were verified by Southern blot analysis of EcoRI-digested DNA with an external 1.4-kb EcoRI-SspI probe (intron 2). Three correctly targeted ES cell clones were injected into $\mathrm{C} 57 \mathrm{BL} / 6$ blastocysts, and chimeric males were mated with C57BL/6 females to obtain $\mathrm{Pax} 8^{\text {neo/+ }}$ offspring. The different Pax 8 alleles were genotyped by PCR with the following primers: 5'-TCTCCACTCCAACATGTCTGC-3' (Pax8 intron 2), 5'-CCCTCCTAGTTGATTCAGCCC-3' (Pax8 exon 3), and $5^{\prime}$-AGCTGGCCCAAATGTTGCTGG-3' (cre gene). The wild-type and $\operatorname{Pax} 8$ mutant alleles gave rise to PCR products of 389 and $673 \mathrm{bp}$, respectively. The $\operatorname{Pax}^{\text {neo }}$ allele (referred to as $\mathrm{Pax}^{-}$allele) was backcrossed into the $\mathrm{C} 3 \mathrm{H} / \mathrm{He}$ genetic background for at least four generations and then crossed into $\mathrm{Pax}^{+/-} \mathrm{C} 3 \mathrm{H} / \mathrm{He}$ mice (Bouchard et al. 2000) to generate doublemutant mice.

\section{In situ hybridization analysis}

Mouse and chick embryos were processed for whole-mount in situ hybridization with digoxigenin-labeled antisense RNA probes as described (Henrique et al. 1995). The mouse Pax2, Pax8, and c-ret probes have been described (Adams et al. 1992; Pachnis et al. 1993). The chicken c-ret probe was generated by RT-PCR cloning of a 1.4-kb cDNA from embryonic head RNA, using the primers 5'-GCGGGGCTTCCTTTGGTCT GT-3' and 5'-ATGTTTCCTGCTCTGCTTGTC-3' (accession no. Z49898). In situ hybridization was combined with immunohistochemical analysis by first performing the in situ hybridization reaction on whole-mount embryos followed by cryosectioning and processing of the $10 \mu \mathrm{m}$ sections for antibody staining.

\section{Immunohistochemical analysis}

Embryos or dissected tissues were fixed and processed for histological or immunohistochemical analysis as described (Bouchard et al. 2000). The following antibodies were used 
for immunostaining: rabbit anti-Pax2 Ab (1:100 dilution; Covance); rabbit anti-laminin $\mathrm{Ab}$ (1:500; Sigma); rabbit anti- $\beta$-galactosidase $\mathrm{Ab}$ (1:1000; Cortex Biochem); rat anti-E-cadherin $\mathrm{Ab}$ (1:200; Zymed Laboratories); mouse anti-Lim1/2 Ab (1:1000; Developmental Studies Hybridoma Bank); and mouse anti-WT1 $\mathrm{Ab}(1: 100 ;$ Dako). Secondary reagents used for detection were the anti-rabbit Vectastain kit (Vector Labs) or Alexa488- or Alexa546-labeled anti-mouse, anti-rabbit, or anti-rat antibodies (1:200; Molecular Probes). DAPI was used for counterstaining at $50 \mu \mathrm{g} / \mathrm{mL}$ in Slow Fade Light mounting medium (Molecular Probes).

\section{$\beta$-Galactosidase and TUNEL staining}

$\beta$-Galactosidase activity was detected by X-gal staining of whole-mount embryos as described (Pfeffer et al. 2000). The fluorescein in situ cell death detection kit (Roche, Mannheim) was used for TUNEL analysis of cryosections that were stained before with a rabbit anti-Pax 2 or rabbit anti- $\beta$-galactosidase antibody.

\section{Retroviral infection of chick embryos}

The mouse Pax2 gene was ectopically expressed in chick embryos by infection with the replication-competent retrovirus RCASBP(A) (Morgan and Fekete 1996) carrying the mPax2b cDNA. The mPax2 coding sequence was PCR-modified by converting the sequence containing the translation start codon into an NcoI site, cloned as a NcoI-HindIII fragment into the shuttle vector Cla12Nco (Hughes et al. 1987) and transferred as a ClaI fragment into the retroviral vector RCASBP(A). The RCASmPax2 virus was produced at a titer of $2 \times 10^{9}$ infectious units/ $\mathrm{mL}$ as described (Morgan and Fekete 1996) and was injected unilaterally next to Hensen's node into the mid-streak tissue of embryos at $\mathrm{HH}$ stages 4-6. Embryos were harvested 48 h postinjection (at HH stages 17-18), and the expression of kidneyspecific genes was analyzed by whole-mount in situ hybridization and immunohistochemistry. The viral infection and ectopic Pax2 expression was monitored by immunostaining with the anti-Gag antibody AMV3C2 (1:1000; Developmental Studies Hybridoma Bank) and an anti-mouse Pax2 antibody (1:200; Covance), respectively. Pathogen-free fertilized White Leghorn eggs (SPAFAS) were obtained from Charles River (Sulzfeld, Germany) and incubated at $37.5^{\circ} \mathrm{C}$ in a rocking incubator. Embryos were staged according to Hamburger and Hamilton (1992).

\section{Accession number}

The mouse Pax 8 gene sequences were submitted to GenBank (accession no. AY157583).

\section{Acknowledgments}

We thank A. Mansouri and Z. Kozmik for Pax8 DNA clones; C. Theu $\beta 1$ for blastocyst injection; G. Schaffner for DNA sequencing; and C. Hartmann for critical reading of the manuscript. This research was supported by Boehringer Ingelheim and by the Austrian Science Foundation (grant P13601-GEN).

The publication costs of this article were defrayed in part by payment of page charges. This article must therefore be hereby marked "advertisement" in accordance with 18 USC section 1734 solely to indicate this fact.

\section{References}

Adams, B., Dörfler, P., Aguzzi, A., Kozmik, Z., Urbánek, P., Maurer-Fogy, I., and Busslinger, M. 1992. Pax-5 encodes the transcription factor BSAP and is expressed in B lymphocytes, the developing CNS, and adult testis. Genes Dev. 6: $1589-1607$.

Barnes, J.D., Crosby, J.L., Jones, C.M., Wright, C.V.E., and Hogan, B.L.M. 1994. Embryonic expression of Lim-1, the mouse homolog of Xenopus XLim-1, suggests a role in lateral mesoderm differentiation and neurogenesis. Dev. Biol. 161: $168-178$.

Bouchard, M., Pfeffer P., and Busslinger, M. 2000. Functional equivalence of the transcription factors Pax2 and Pax5 in mouse development. Development 127: 3703-3713.

Bouchard, M., Schleiffer, A., Eisenhaber, F., and Busslinger, M. 2003. Evolution and function of Pax genes. In Encyclopedia of the Human Genome (ed. D. Cooper). Nature Publishing Group, UK. (In Press.)

Brophy, P.D., Ostrom, L., Lang, K.M., and Dressler, G.R. 2001. Regulation of ureteric bud outgrowth by Pax2-dependent activation of the glial derived neurotrophic factor gene. Development 128: 4747-4756.

Carroll, T.J. and Vize, P.D. 1999. Synergism between Pax-8 and lim-1 in embryonic kidney development. Dev. Biol. 214: 4659.

Coles, H.S., Burne, J.F., and Raff, M.C. 1993. Large-scale normal cell death in the developing rat kidney and its reduction by epidermal growth factor. Development 118: 777-784.

Czerny, T., Schaffner, G. and Busslinger, M. 1993. DNA sequence recognition by Pax proteins: Bipartite structure of the paired domain and its binding site. Genes \& Dev. 7: 20482061.

Davies, J.A. and Brändli, A.W. 2002. The Kidney Development Database. http://golgi.ana.ed.ac.uk/kidhome.html.

Donovan, M.J., Natoli, T.A., Sainio, K., Amstutz, A., Jaenisch, R., Sariola, H., and Kreidberg, J.A. 1999. Initial differentiation of the metanephric mesenchyme is independent of WT1 and the ureteric bud. Dev. Genet. 24: 252-262.

Drawbridge, J., Meighan, C.M., and Mitchell, E.A. 2000. GDNF and GFRa-1 are components of the axolotl pronephric duct guidance system. Dev. Biol. 228: 116-124.

Dressler, G.R., Deutsch, U., Chowdhury, K., Nornes, H.O., and Gruss, P. 1990. Pax2, a new murine paired-box-containing gene and its expression in the developing excretory system. Development 109: 787-795.

Dudley, A.T., Godin, R.E., and Robertson, E.J. 1999. Interaction between FGF and BMP signaling pathways regulates development of metanephric mesenchyme. Genes \& Dev. 13: 1601-1613.

Favor, J., Sandulache, R., Neuhäuser-Klaus, A., Pretsch, W., Chatterjee, B., Senft, E., Wurst, W., Blanquet, V., Grimes, P., Spörle, R., et al. 1996. The mouse Pax21Neu mutation is identical to a human $P A X 2$ mutation in a family with renalcoloboma syndrome and results in developmental defects of the brain, ear, eye, and kidney. Proc. Natl. Acad. Sci. 93: $13870-13875$.

Fekete, D.M. and Cepko, C.L. 1993. Replication-competent retroviral vectors encoding alkaline phosphatase reveal spatial restriction of viral gene expression/transduction in the chick embryo. Mol. Cell. Biol. 13: 2604-2613.

Fujii, T., Pichel, J.G., Taira, M., Toyama, R., Dawid, I.B., and Westphal, H. 1994. Expression patterns of the murine LIM class homeobox gene $\operatorname{Lim} 1$ in the developing brain and excretory system. Dev. Dyn. 199: 73-83. 
Godin, R.E., Takaesu, N.T., Robertson, E.J., and Dudley, A.T. 1998. Regulation of BMP7 expression during kidney development. Development 125: 3473-3482.

Hamburger, V. and Hamilton, H.L. 1992. A series of normal stages in the development of chick embryos. Dev. Dyn. 195: 231-272.

Heller, N. and Brändli, A.W. 1999. Xenopus Pax-2/5/8 orthologues: Novel insights into Pax gene evolution and identification of Pax- 8 as the earliest marker of otic and pronephric cell lineages. Dev. Genet. 24: 208-219.

Henrique, D., Adam, J., Myat, A., Chitnis, A., Lewis, J., and Ish-Horowicz, D. 1995. Expression of a Delta homologue in prospective neurons in the chick. Nature 375: $787-$ 790.

Hughes, S.H., Greenhouse, J.J., Petropoulos, C.J., and Sutrave, P. 1987. Adaptor plasmids simplify the insertion of foreign DNA into helper-independent retroviral vectors. J. Virol. 61: 3004-3012.

Kreidberg, J.A., Sariola, H., Loring, J.M., Maeda, M., Pelletier, J., Housman, D., and Jaenisch, R. 1993. WT-1 is required for early kidney development. Cell 74: 679-691.

Kuure, S., Vuolteenaho, R., and Vainio, S. 2000. Kidney morphogenesis: Cellular and molecular regulation. Mech. Dev. 92: 31-45.

Majumdar, A., Lun, K., Brand, M., and Drummond, I.A. 2000. Zebrafish no isthmus reveals a role for pax2.1 in tubule differentiation and patterning events in the pronephric primordia. Development 127: 2089-2098.

Mansouri, A., Chowdhury, K., and Gruss, P. 1998. Follicular cells of the thyroid gland require Pax8 gene function. Nature Genet. 19: 87-90.

Mauch, T.J., Yang, G., Wright, M., Smith, D., and Schoenwolf, G.C. 2000. Signals from trunk paraxial mesoderm induce pronephros formation in chick intermediate mesoderm. Dev. Biol. 220: 62-75.

Meyers, E.N., Lewandoski, M., and Martin G.R. 1998. An Fgf8 mutant allelic series generated by Cre- and Flp-mediated recombination. Nature Genet. 18: 136-141.

Moore, M.W., Klein, R.D., Fariñas, I., Sauer, H., Armanini, M., Phillips, H., Reichardt, L.F., Ryan, A.M., Carver-Moore, K., and Rosenthal, A. 1996. Renal and neuronal abnormalities in mice lacking GDNF. Nature 382: 76-79.

Morgan, B.A. and Fekete, D.M. 1996. Manipulating gene expression with replication-competent retroviruses. Methods Cell. Biol. 51: 185-218.

Nutt, S.L., Heavey, B., Rolink, A.G., and Busslinger, M. 1999. Commitment to the B-lymphoid lineage depends on the transcription factor Pax5. Nature 401: 556-562.

Obara-Ishihara, T., Kuhlman, J., Niswander, L., and Herzlinger, D. 1999. The surface ectoderm is essential for nephric duct formation in intermediate mesoderm. Development 126: $1103-1108$.

Okladnova, O., Poleev, A., Fantes, J., Lee, M., Plachov, D., and Horst, J. 1997. The genomic organization of the murine Pax 8 gene and characterization of its basal promoter. Genomics 42: 452-461.

Ostrom, L., Tang, M.J., Gruss, P., and Dressler, G.R. 2000. Reduced Pax2 gene dosage increases apoptosis and slows the progression of renal cystic disease. Dev. Biol. 219: 250258.

Pachnis, V., Mankoo, B., and Costantini, F. 1993. Expression of the $c$-ret proto-oncogene during mouse embryogenesis. Development 119: 1005-1017.

Perantoni, A.O., Dove, L.F., and Karavanova, I. 1995. Basic fibroblast growth factor can mediate the early inductive events in renal development. Proc. Natl. Acad. Sci.
92: 4696-4700.

Pfeffer, P.L., Gerster, T., Lun, K., Brand, M., and Busslinger, M. 1998. Characterization of three novel members of the zebrafish Pax2/5/8 family: Dependency of Pax 5 and Pax 8 expression on the Pax2.1 (noi) function. Development 125: 3063-3074.

Pfeffer, P.L., Bouchard, M., and Busslinger, M. 2000. Pax2 and homeodomain proteins regulate a $435 \mathrm{bp}$ enhancer of the mouse Pax5 gene at the midbrain-hindbrain boundary. Development 127: 1017-1028.

Pfeffer, P.L., Payer, B., Reim, G., Pasca di Magliano, M., and Busslinger, M. 2002. The activation and maintenance of Pax2 expression at the mid-hindbrain boundary is controlled by separate enhancers. Development 129: 307318.

Pichel, J.G., Shen, L., Sheng, H.-Z., Granholm, A.-C., Drago, J., Grinberg, A., Lee, E.J., Huang, S.P., Saarma, M., Hoffer, B.J., et al. 1996. Defects in enteric innervation and kidney development in mice lacking GDNF. Nature 382: 73-76.

Plachov, D., Chowdhury, K., Walther, C., Simon, D., Guenet, J.L., and Gruss, P. 1990. Pax8, a murine paired box gene expressed in the developing excretory system and thyroid gland. Development 110: 643-651.

Porteous, S., Torban, E., Cho, N.-P., Cunliffe, H., Chua, L., McNoe, L., Ward, T., Souza, C., Gus, P., Giugliani, R., et al. 2000. Primary renal hypoplasia in humans and mice with PAX2 mutations: Evidence of increased apoptosis in fetal kidneys of Pax21Neu +/- mutant mice. Hum. Mol. Genet. 9: $1-11$.

Rothenpieler, U.W. and Dressler, G.R. 1993. Pax-2 is required for mesenchyme-to-epithelium conversion during kidney development. Development 119: 711-720.

Sainio, K., Hellstedt, P., Kreidberg, J.A., Saxén, L., and Sariola, H. 1997. Differential regulation of two sets of mesonephric tubules by WT-1. Development 124: 1293-1299.

Sánchez, M.P., Silos-Santiago, I., Frisén, J., He, B., Lira, S.A., and Barbacid, M. 1996. Renal agenesis and the absence of enteric neurons in mice lacking GDNF. Nature 382: 70-73.

Sander, M., Neubüser, A., Kalamaras, J., Ee, H.C., Martin, G.R., and German, M.S. 1997. Genetic analysis reveals that PAX6 is required for normal transcription of pancreatic hormone genes and islet development. Genes \& Dev. 11: 16621673.

Saxén, L. 1987. Organogenesis of the kidney. Cambridge University Press, Cambridge, UK.

Schuchardt, A., D'Agati, V., Larsson-Blomberg, L., Costantini, F., and Pachnis, V. 1994. Defects in the kidney and enteric nervous system of mice lacking the tyrosine kinase receptor Ret. Nature 367: 380-383.

Seale, P., Sabourin, L.A., Girgis-Gabardo, A., Mansouri, A., Gruss, P., and Rudnicki, M.A. 2000. Pax7 is required for the specification of myogenic satellite cells. Cell 102: 777786.

Shawlot, W. and Behringer, R.R. 1995. Requirement for Lim1 in head-organizer function. Nature 374: 425-430.

Sosa-Pineda, B., Chowdhury, K., Torres, M., Oliver, G., and Gruss, P. 1997. The Pax4 gene is essential for differentiation of insulin-producing b cells in the mammalian pancreas. $\mathrm{Na}$ ture 386: 399-402.

Souabni, A., Cobaleda, C., Schebesta, M., and Busslinger, M. 2002. Pan-hematopoietic expression of Pax5 (BSAP) promotes B cell development at the expense of T-lymphopoiesis and erythroblast formation. Immunity (In press).

St-Onge, L., Sosa-Pineda, B., Chowdhury, K., Mansouri, A., and Gruss, P. 1997. Pax6 is required for differentiation of gluca- 
Bouchard et al.

gon-producing a-cells in mouse pancreas. Nature 387: 406409.

Torban, E., Eccles, M.R., Favor, J., and Goodyer, P.R. 2000. PAX2 suppresses apoptosis in renal collecting duct cells. Am. J. Pathol. 157: 833-842.

Torres, M., Gómez-Pardo, E., Dressler, G.R., and Gruss, P. 1995. Pax-2 controls multiple steps of urogenital development. Development 121: 4057-4065.

Tsang, T.E., Shawlot, W., Kinder, S.J., Kobayashi, A., Kwan, K.M., Schughart, K., Kania, A., Jessell, T.M., Behringer, R.R., and Tam, P.P.L. 2000. Lim1 activity is required for intermediate mesoderm differentiation in the mouse embryo. Dev. Biol. 223: 77-90.

Vainio, S. and Müller, U. 1997. Inductive tissue interactions, cell signaling, and the control of kidney organogenesis. Cell 90: 975-978.

Ye, W., Bouchard, M., Stone, D., Luo, X., Vella, F., Lee, J., Nakamura, H., Ang, S.-L., Busslinger, M., and Rosenthal, A. 2001. Distinct regulators control the induction, positioning and maintenance of the mid-hindbrain organizer signal FGF8. Nature Neurosci. 4: 1175-1181. 


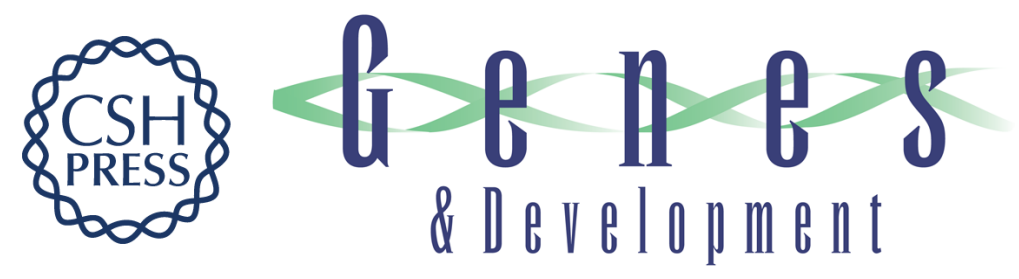

\section{Nephric lineage specification by Pax2 and Pax8}

Maxime Bouchard, Abdallah Souabni, Markus Mandler, et al.

Genes Dev. 2002, 16:

Access the most recent version at doi:10.1101/gad.240102

References This article cites 53 articles, 23 of which can be accessed free at: http://genesdev.cshlp.org/content/16/22/2958.full.html\#ref-list-1

License

Email Alerting Receive free email alerts when new articles cite this article - sign up in the box at the top Service right corner of the article or click here.

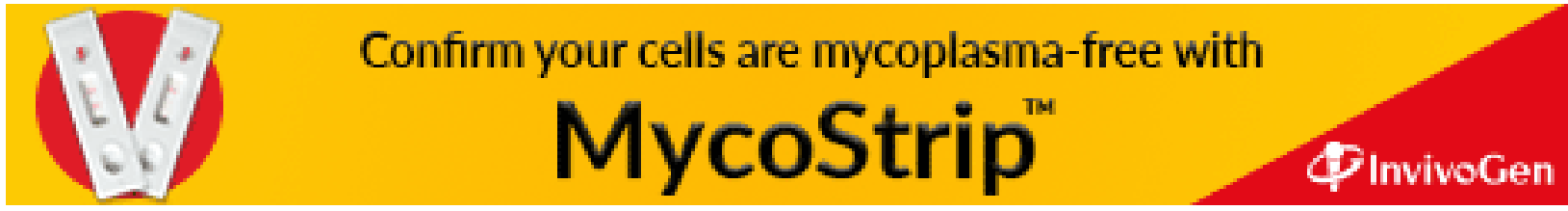

